\title{
Miriam Friedman Ben David (1938-2004)
}

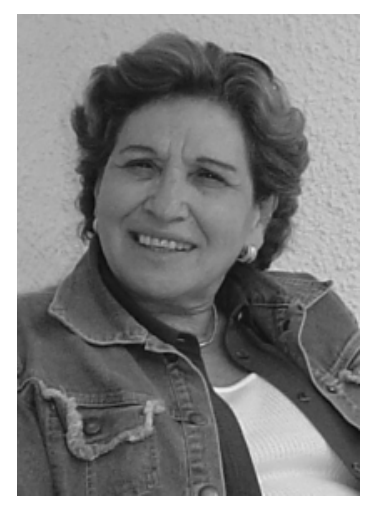

Miriam Friedman
irrumpe en el ámbito
de la educación médica
europea asistiendo a la
Conferencia de AMEE
que se celebra en
Lisboa en la década de
los 80 . Sus intervencio-
nes expresan con clari-
dad la joven y dinámi-
ca personalidad de
Miriam. Siempre ha
sido una AMEE adicta.
En efecto, en aquélla década Miriam está comprometida con la Facultad de Ciencias Médicas de la Universidad de BenGurion en el Neguev, con todas sus capacidades puestas al servicio de la creación de un centro nacional de educación médica en Israel y la finalización de $\mathrm{su} \mathrm{PhD}$ sobre razonamiento y juicio clínico de los estudiantes de Medicina. Previamente, en los 70, estudia y desarrolla su profesión como educadora en la Universidad de Wisconsin (EEUU) enfocando su actividad hacia tareas de evaluación; entra posteriormente en contacto con la educación médica en el Medical College de Wisconsin; ya nunca se apartará, todo lo contrario, crecerá profesionalmente al lado de la educación médica y ésta crecerá con y por ella.

$\mathrm{Su}$ presencia y aportaciones en reuniones internacionales de educación médica es constante, si bien su trabajo profesional se desarrolla en EEUU (19891999) en Escuelas de Medicina de los estados de New México y Pennsylvania y en la Educational Commission for Foreign Medical Graduates (ECFMG) de Philadelphia, al tiempo que asesora a prestigiosas instituciones internacionales. Ejerce su magisterio, y lidera proyectos de impacto y consecuencias que trascienden lo local y se amplifican en el tiempo y el espacio tras su ejecución. En Madrid y en Barcelona, en Ucrania, en Brasil, en Italia, en Israel... la puesta en práctica, bajo su dirección y bajo los auspicios de ECFMG, del modelo de evaluación de habilidades clínicas con pacientes simulados, indican todo la generosidad que Miriam es capaz de poner al servicio de la innovación y el progreso internacional de la educación médica. En los Congresos de la Sociedad Española de Educación Médica (SEDEM), Miriam es una invitada habitual. Desde aquí SEDEM la rinde el tributo que merecen
Miriam Friedman made her mark in the world of European medical education at the AMEE Conference in Lisbon in the mid 1980's. In all her interventions Miriam's youthful and dynamic personality always shone through, and to the end she remained a faithful member of the AMEE.

During the nineteen eighties, Miriam worked at the Faculty of Medical Science at Ben Gurion University in the Negev, and all her efforts were devoted towards the creation of a national centre for medical education in Israel and the completion of her $\mathrm{PhD}$ on clinical reasoning and judgment in medicine students. Previously, in the nineteen seventies, she had studied and worked at the University of Wisconsin as an educator focusing on assessment tasks. She went on to gain first-hand knowledge of medical education at Wisconsin Medical College, and indeed never left the field. She established herself professionally in the medical education community, and medical education developed thanks to her.

She was a keen participant in international meetings on medical education, though she built her carrier in the United States (1989-1999) at medical schools in New Mexico and Pennsylvania, and in the Educational Commission for Foreign Medical Graduates (ECFMG) in Philadelphia, and was also a consultant to leading international organizations. Her teaching and the series of projects that she led had a far-reaching impact. In Madrid and Barcelona, in Ukraine, Brazil, Italy, and Israel, under her guidance and under the auspices of the ECFMG, the implementation of the model for the evaluation of clinical skills in simulated patients is an example of her generosity of spirit and her commitment to innovation and international progress in medical education. Miriam was regularly invited to the congresses of the Spanish Society for Medical Education (SEDEM), and the Society is proud now to pay her the tribute she deserves. In 1994, Miriam Friedman returned to the AMEE conferences in Athens, now as Miriam Friedman Ben David, together with her inseparable companion Shaoul Ben David. An economist by education, his involvement in Miriam's professional and social life was remarkable, so much so that he is now working hard to finish the projects that she would never be able to finish. In 1999 she moved to Dundee 
sus aportaciones. Entre tanto, en 1994 Miriam Friedman irrumpe de nuevo en la Conferencia de AMEE en Atenas, esta vez como Miriam Friedman Ben David, acompañada de su inseparable pareja Shaoul Ben David. El es economista, lo cual podría ser simplemente anecdótico, mas no deja de ser interesante su integración y compromiso con la vida profesional y social de Miriam, de tal suerte, que actualmente continúa los proyectos inconclusos de ella. En 1999 se instala en Dundee (Escocia, RU) como consultora y profesora visitante en el Centro de Educación Médica de aquella Universidad. Como es habitual, Miriam se integra perfectamente en su nuevo ambiente colaborando además con la sociedad médica escocesa en la evaluación de sus postgraduados.

Miriam Friedman y Miriam Friedman Ben David deja una profunda huella en la educación médica internacional, cuya herencia abarca diversos campos de la misma, desde la innovación curricular hasta la formación de formadores y de jóvenes que habrían de ser expertos, su último proyecto. Sin embargo, si es preciso identificar el perfil que mejor define sus resultados de investigación y desarrollo profesional, se advierte sin temor a errar que su área preferida ha sido la de la evaluación. Las palabras evaluation, assessment, measure, son las que con mayor frecuencia presiden el título de sus numerosas publicaciones internacionales (mas de 70). Este hecho refleja con exactitud la personalidad científica, veraz y competente de Miriam Friedman y... también la humana por su afán de conocer la realidad en sus relaciones interpersonales; es curioso que sus amistades perciban en determinados momentos que Miriam está haciendo un ejercicio profundo de valoración y apreciación de sus personas y de sus circunstancias.

He tratado de no sucumbir al uso del verbo en pasado ni a la utilización de la primera persona del singular o plural, esto último se hace ya imposible y debo claudicar. Me consta que todo lo dicho sería suscrito por todas las personas que, al menos en España e Iberoamérica, hemos tenido la fortuna de encontrar a Miriam Friedman Ben David, de ser sus amigas y sus amigos, de enriquecernos con sus conocimientos y competencia como educadora médica y de disfrutar de sus hermosas e innumerables cualidades humanas: global, integradora, generosa, leal, arriesgada, innovadora, simpática, cercana, cariñosa... Y digo en nombre todas esas personas y en el mío propio: Miriam te queremos y te admiramos.

Margarita Barón Maldonado Octubre de 2004
(Scotland) as a consultant and visiting professor at the Centre for Medical Education at Dundee University. Miriam soon adapted to this new environment, and collaborated with the Scottish medical society in post-graduate assessment.

Miriam Friedman, Miriam Friedman Ben David, left a profound impression in international medical education. Her legacy covers many areas, from curriculum innovation to training educators and students to make them into experts, which was her last project. Nevertheless, if we were to choose the profile that best defines the results of her research and work, we would have to opt for her favourite area: assessment. The words evaluation, assessment, and measure abound in the titles of her numerous international publications (more than 70). This is an accurate reflection of Miriam Friedman's personality: scientific, exact and effective, but also her human dimension, her determination to understand interpersonal relationships. Interestingly, her friends say that Miriam would sometimes seem to be evaluating and appraising their personalities and circumstances.

I know the words I have written will be shared by all those of us who, at least in Spain and Iberoamerica, have been lucky enough to have known Miriam Friedman Ben David, to have been her friends, to have benefited from the wealth of her knowledge and ability as a medical educator, to have had the pleasure of her company, to have appreciated her human qualities: her generosity, her loyalty, her audacity, her love of innovation, her closeness, her warmth ... In my name and in the name of all those who knew her: Miriam, we will always love and admire you.

Margarita Barón Maldonado October 2004 